Earth community, green women, and people-centered altruistic economies, politics and cultures: A book summary and review of 'The Great Turning from Empire to Earth Community' (2006)

Rouf, Kazi Rouf $\bowtie$

University of Toronto, Canada (ouf.kazi@utoronto.ca)

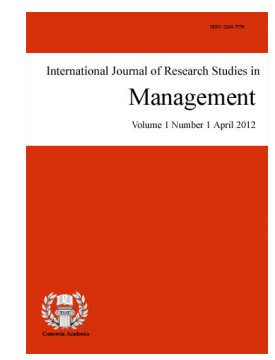

ISSN: $2243-7770$ Online ISSN: 2243-7789

OPEN ACCESS

\title{
Abstract
}

David Korten, in his book 'The Great Turning from Empire to Earth Community' (2006), presents a well-researched summary of human socio-cultural history over the past 10,000 or so years. Before $3000 \mathrm{BC}$, he argues, human society was organized on the basis of relationships in a form of social organization he terms "Earth Community". Human needs and values were paramount; cooperation was the basic principal of interaction; the earth was respected, and the needs the individual were humanely balanced with the needs of the group. Before Empire, spiritually, Gods were generally female, representing the givers of life and sustenance. In human society, women enjoyed a status of full participation, with a voice in all family and village affairs. However, in different periods of empire, women's egalitarian status transformed and was lost to patriarchal male domination. To eradicate injustice, inequality and exploitation from society, it is important to revive the earth community in order to restore justice and equality in the contemporary society.

Keywords: earth community; community driven economics; people centered ecological economics 


\section{Earth community, green women, and people-centered altruistic economies, politics and cultures: A book summary and review of 'The Great Turning from Empire to Earth Community' (2006)}

\section{Significance of the book review}

This book creates new knowledge, thoughts and strategies that inspire people to organize them against exploiting empires and to develop partnerships among marginalised people for their well-being in the community. It tells us how to use human potential for creative cooperation and share resources for the creation of community-driven economies that are green, smart, and promote the well-being of all people. This book review promotes a bio-diverse green economy and green women development based on Korten's 'Earth Community' approach. The reviewer of this book thinks this book summary and review provide readers with a synopsis of the book and share David Korten's 'Earth Community' features that might help researchers think and find out ways of making better altruistic community life in the contemporary world.

\section{Summary and review of the book}

In the book, Korten uses two terms: 'Empire' and 'Earth Community'. These two terms are opposite to each other. The first term means to dominate people and the other refers to cooperation among people for the benefit of community well-being. Empire organizes human society through domination at all levels and gives fortune to only a few people. Korten maintains that "Earth Community... organizes by partnership, unleashes the human potential for creative cooperation, and shares resources and surpluses for the good of all." (p. 33). Then, in ancient Mesopotamia and Egypt, a new basis of organization arose: the Empire state, which was hierarchical and controlled by a relatively small elite and their entourages. The great majority of individuals were impoverished, with their needs being subordinated to the needs of the ruling elite. In Korten's words "Empire organizes by domination at all levels, from relations among nations to relations among family members. Empire brings fortune to the few, condemns the majority to misery and servitude, suppresses the creative potential of all, and appropriates much of the wealth of human societies to maintain the institutions of domination" (p. 20).

During this period and after, spiritually, gods were more often male, and represented rulers and controllers. Most earthly rulers were also male. The role and the powers of women were diminished. Below, Part A provides a summary and Part B is the review of the book.

\subsection{Part A: Summary}

The book 'The Great Turning from Empire to Earth Community' has twenty-two chapters in five parts. In the first part of the book, called 'Choosing Our Future', Korten uses two terms: 'Empire' and 'Earth Community'. 'Empire' dominates at all levels of society from ancient time to today. In contrast, 'Earth Community' features partnership organizations and unleashes the human potential for cooperation. This 'Earth Community' is the reflection of collective human creativity and collective choice. However, individual choice is limited in Empire.

Chapter two discusses cultural and spiritual consciousness-raising through socialization in society. Although Empire suppresses development of human consciousness and creates a self-fulfilling prophecy, humans are the architects of their own nature and future. In Chapter three and four, Korten explains that although Empires dominate the society, they have reached the limits of social and environmental exploitation because recent global communication technologies break down imperial domination and allow the Earth Community to prosper.

Part two of the book gives us information about the history of different empires such as Mesopotamia, Rome, Egypt, and Greece. It is important to understand the dynamics of empires and the consequences of their 
Earth community, green women, and people-centered altruistic economies, politics and cultures

destruction because this knowledge can help us to liberate ourselves from the brutality of empires. Chapter five is about feminism in empires. Empires denied women power, and they were aggressive, often assaulting women. The new rulers robbed public wealth and discriminated against women. Chapter seven mentions that there is a democratic challenge to the power of these modern empires. The Empire's ruling classes maintain their control over the lives of ordinary people and the resources through allocation of money to different communities.

In part three, Korten highlights citizen challenges even in democratic America. America's imperial legacy hampers the Earth Community. Black people and women are struggling for justice in society. Although Earth Community is characterized by deep democracy, justice to all people is difficult to realize.

Chapter ten is titled 'People Power Rebellion'. Here the author describes an empire's victory where colonial elites win. The focus then shifts to security and the interests of industrialists and bankers. The landed aristocracies have their imperial privileges put at risk as the oppressed revolt against them. The emperors create stories in their own interest that help them perpetuate their own politics, economy, and power. Retelling new stories of the new Empire make new hierarchies of domination. The people need to organize themselves and force the few exploiters to distribute their wealth more fairly.

To escape Empire's control, Korten mentions in Part four that it is time to put the sorrows of the Empire behind in favour of the Earth Community. He urges use of contemporary knowledge, technology, religion, and science, building the Earth Community through mutual cooperation. Korten says that these challenges can create an epic journey of self-discovery (chapter sixteen). This determination can open doors to living communities and living economies with diverse and mutual benefits to common people.

According to chapter seventeen, the Earth Community is an alternative to the alienation and sorrows of Empire. It places life values ahead of financial values, and organizes by the principles of partnership rather than principles of domination. Here, deeper mutual relationships affirm all people. This Earth Community bonding helps people to challenge the Empire's power and privilege. Chapter eighteen gives us life-denying stories of the Empire which cannot compete with the life-affirming stories of the Earth Community. The new stories of the deep human yearning for a healthy community can create a new era for the Earth Community.

The last part of the book, titled 'Birthing Earth Community', talks about leadership for birthing the great new era. This new turning makes the choice for life, gives expression to the higher potential of nature, and restores families and community power. Here leadership comes from below through a process of mutual empowerment. To liberate ourselves from domination by empire, we need to make wise and creative choices. This will give birth to the Earth Community, and liberate our minds from tyranny and the belief that there is no alternative to the Empire. It allows us to move forward and glimpse the possibilities of human capacity. The process of change begins through consciousness-raising. Korten believes that in this process people can easily find one another, share their insights, and celebrate the possibilities of Earth Community and cultural balance.

\subsection{Part B: Review}

As empires rose and fell and technology became more complex, economic power eventually became concentrated in the corporations of the Western World, and human values were subordinated to the bottom-line profits of corporations. Over the past century or two, technology has helped corporations create vast wealth unimagined by earlier human standards. Especially in the past century, the production of vast wealth and the power that accompanied it have been based on the availability of cheap energy, chiefly from petroleum. Americans have benefited so much from inexpensive petroleum that it has helped the U.S. become the dominant world power, the center of a new world empire based on the corporate state. In the early years of the 21st century, the world system based on the American corporate state faces a devastating collapse.

Korten predicts there are three conditions, occurring more or less simultaneously, that will cause this collapse: (1) Petroleum production will peak and then decline, and its prices will rise, (2) Global warming and 
climate change, already evident, will ravage much of the earth, and (3) Military force can no longer be used to take resources from weaker nations (pp. 70-71). While no one can predict with accuracy when each of these events will occur, most analysts agree this devastation will happen within the next few decades. And there are other potentially destructive processes at work. The entire world is marked by gross and growing inequity between rich and poor nations, and between rich and poor people within the nations.

Poverty promises massive unrest and civil strife. Further, the world empire is based on a corporate system that has no role for the satisfaction of human needs and the nurturing of human values. The Empire system bottom line is to rule people. Employees, even at the top of corporate structures, are required to perform amorally, and they are unaccountable to an alarming degree. Governments, now controlled by corporate interests, are allowed to cater to human needs up to a point, keeping the myth of democracy alive. The corporate bottom line is profit for shareholders/stockholders. This creates great inequality in the society. Korten's dire analysis is based on careful research, and its main conclusions echo those of other perceptive analysts.

A catastrophic collapse of the American empire, and consequently the world socioeconomic system, seems certain within the next few decades. Yet Korten offers an inspiring vista of hope in his Earth Community. He argues that there is a healthy alternative to collapse and ruin as the world begins to build a new Earth Community, marked by close interpersonal relationships, adherence to such human values as mutual caring and cooperation, respect for the earth, and commitment to peaceful living. This he calls 'The Great Turning', and he believes it is already underway, on a limited scale, in the civil rights, feminist, environmental, peace, and other social movements. Individuals active in these movements can be buoyed by the knowledge that recent polls reveal a profound consensus among Americans - rich, poor, liberal, conservative - on basic principles. Korten says, " $83 \%$ believe the U.S. is focused on the wrong priorities" (Lecture at York University, October 16, 2007).

In Korten's words, huge majorities want "... greater priority given to children, family, community, and a healthy environment, as well as a world that puts people ahead of profits, spiritual values ahead of financial values, and international cooperation ahead of international domination" (p. 327). Korten ends his appeal by urging that all activists who share these values, whatever their political persuasion work harder to mobilize the people of the world to work together to build a new Earth Community. He points out that the new revolution in communication and transportation will facilitate this cooperative endeavour which offers the only hope for averting disastrous collapse.

In the book, Korten contrasts the Empire and the Earth Community:

Empire

Hostile and competitive

Humans are flawed and dangerous

Order by domination and hierarchy

Compete or die

Love power

Defend the rights of the self

Male dominant
Earth Community

Life is supportive and cooperative

Humans have many possibilities

Order through partnership

Cooperate and live

Love life

Defend the rights of all

Gender balanced

Source: Table 1.1, p. 33

Korten also differentiates Empire and the Earth Community by their cultural consciousness and organizes them into five orders (p. 54): 
Earth community, green women, and people-centered altruistic economies, politics and cultures

$>$ First Order: Magical Consciousness: Dreamers live in an Other World and place their faith in magical protectors.

$>$ Second Order: Imperial Consciousness: Power Seekers live in My World, play up to the powerful, and exploit the oppressed.

$>$ Third Order: Socialized Consciousness: Good Citizens live in a Small World, play by the rules of their identity group, expect a fair reward, and comprise the swing voters.

Fourth Order: Cultural Consciousness: Cultural Creative lives in an Inclusive World and sees the possibility of creating inclusive, life-affirming societies that work for all.

Fifth Order: Spiritual Consciousness: Spiritual Creative lives in a complex, evolving Integral World, which they engage as evolutionary co-creators.

The third order is the dividing line between the Culture of Empire and the Culture of Earth Community. When people move through the Third Order to the later Orders they join the Culture of Earth Community. According to Korten, the transformation of Empire to Earth Community has three turning points: cultural turning, economic turning, and political turning (p. 322).

Corporate businesses and institutions get enormous power and expand their wealth by turning the human race into cog-labour. Therefore, corporations are powerful engines of wealth concentration. $85 \%$ of the resources of the planet are appropriated by $20 \%$ of the world's people. $20 \%$ are the poorest people and exist on $1 \%$, and $60 \%$ are the middle class people and exist on $14 \%$ of resources (Korten lecture at York University, October 16, 2006). The Empire's capitalist dehumanization process creates this disparity in the world. Korten says, "It is also impacted through oil price skyrocketing. It is the 'Peak Oil Impact' “(p. 61).

This wealth disparity affects human-centered ecological economics and results in air pollution, global warming and climate change. To change peak oil economics, the credit-card debt economy and the corporation-dominating economy, the author suggests an alternative economy which can turn human crises to human opportunities and enhance domestic markets. Korten termed it 'the perfect economic storm' (p. 70). Through this perfect economic storm, imperial power turns to community power, and develops human enterprises (p. 34). However, he did not mention any paths for ending exploitation of people by corporations, although community caring benefits and supports people's prosperity (p. 298). Korten did not identify how empire can end for the betterment of people-centered economic development. He raised the issue of imperial domination with historical evidence. Many corporate stories show that the world is still ruled by the plutocracy (p. 161), autocracy and colonial imperial power. However, Korten hopes that the three turnings-cultural turning, economic turning, and political turning — can effect a positive change to Earth Community.

Cultural Turning: Here the Great Turning begins with a cultural and spiritual awakening-a turning in cultural values from money and material excess to life and spiritual fulfillment, from a belief in limitations to a belief in possibilities, and from fearing differences to rejoicing in diversity. It requires reframing the cultural stories by which we define our human nature, purpose, and possibilities.

Economic Turning: The values-shift of the cultural turning leads us to redefine wealth-to measure it by the health of families, communities, and the natural environment. It leads us from policies that raise those at the top to policies that raise those at the bottom, from hoarding to sharing, from concentrated to distributed ownership, and from the rights of ownership to the responsibilities of stewardship.

Political Turning: The economic turning creates the necessary conditions for a turn from a one-dollar, one-vote democracy to a one-person, one-vote democracy, from passive to active citizenship, from competition for individual advantage to cooperation for mutual advantage, from retributive justice to restorative justice, and from social order by coercion to social order by mutual responsibility and accountability. 
The above three turnings do not take place in the same order in all societies. Korten mentions the following critical distinguishing features in the economics of Global Empire and Local Living (p. 343).

\begin{tabular}{|l|l|}
\hline \multicolumn{1}{|c|}{ Global Empire } & \multicolumn{1}{c|}{ Local Living } \\
\hline Global Imperial Economy & Local Living Economies \\
\hline $\begin{array}{l}\text { The defining purpose is to make to increase their } \\
\text { power }\end{array}$ & To secure fulfilling livelihoods for all \\
\hline $\begin{array}{l}\text { The guiding mantra is to create global monopolies } \\
\text { to eliminate local choice }\end{array}$ & The guiding mantra is to create beneficial local options \\
\hline $\begin{array}{l}\text { The rules favour absentee owners, } \\
\text { monopoly-scale enterprises and central planning } \\
\text { by Global Corporations. }\end{array}$ & $\begin{array}{l}\text { The rules favour participating owners, human-scale } \\
\text { enterprises, wealth creators, rights of people, and } \\
\text { self-organization by people and communities. }\end{array}$ \\
\hline Denying responsibility for public interests & $\begin{array}{l}\text { Recognizing the need for all living entities to protect } \\
\text { and balance individual and community interests }\end{array}$ \\
\hline
\end{tabular}

Although the above local living economies are people-centered and have multiple effects in Earth Community, the benefits are wiped away by the powerful and hegemonic global imperial economy. Hence Korten suggests four strategies for Turning to Earth Community (p. 316): (1) Accelerate the awakening of cultural and spiritual consciousness, (2) Resist empire's assault on children, families, community and nature, (3) Form and connect communities of congruence, (4) Build a majority political base.

Korten says, "Local living economies liberate the creative potential of the people." (p. 342). He believes that the characteristics of living economies are as follows:

$>\quad$ Economic Democracy

$>\quad$ Local Preference - local needs met by local businesses

$>\quad$ Human Scale - foster face-to-face human relationships

$>$ Fair-share Taxation

$>$ Responsive Markets - businesses respond to self-defined needs of the people

$>\quad$ Responsibility for Harms Caused

$>\quad$ Information and Technology

$>$ Economic Self-Determination - citizens must control their own economic future

$>\quad$ Fair and Balanced Trade - prices must reflect full costs

Korten also mentions two other terms in the book: living politics and living culture (pp. 345-349). He feels that living politics feature independent media, an open political process, the right to vote, public financing (of elections), voting integrity, non-partisan election administration, direct election based on one-person-one-vote, media access, open debates, equal representation and political rights for people. Moreover, Korten's idea of living cultures is one of the Great Turning's most important challenges. The four primary institutions of imperial culture - family, education, media and religion - are institutions of living culture supportive of authentic cultural expression and the higher orders of consciousness.

Korten writes this book (the Great Turning) from his contemporary life experience growing up in a homogeneous white middle-class Christian community in the U.S., and residing and working in Africa and Asia. He finds modern models of economic development increase exclusion of most people, create an inequality and gap between rich and poor, and destroy the environment. Korten explains in this book that the current devastation is rooted in historical imperialism that started in ancient empires, and created turmoil in the Middle Ages, and feudalism in Byzantine, Islamic and Western Christian empires (p. 122). Empires have passed these 
Earth community, green women, and people-centered altruistic economies, politics and cultures

exploitations to the modern industrial capitalist society. Ruling groups denied humanity and put many people into positions of servitude (Korten lecture on October 16, 2007) to maintain the domination of the empire through propaganda. This oppression will continue as long as empire exists. This exploitative process runs through the modern democratic society. Korten suggests that global corporate empires need to negotiate with the state to end corporate power and privileges (p. 125). This process can enhance feminism-valuing women and egalitarian structure in the society. Korten calls it the 'Earth Community Model'- the way to transition to a people partnership (p. 5).

Now corporations influence and rule the world, and are increasing their exploitative power. David Korten (2006) points out that post-corporate hegemonic globalization processes are expanding all over the world and increasing corporate profits. North America has had a significant role in creating the monumental mess. Contemporary corporate globalization is far more dominant than local living economies and healthy communities. To move toward local living economies, Korten suggests an open political process that includes all citizens' rights to vote and unbiased media access to open political debates (p. 347-349). Through these processes, unbiased political representation can counter corporate money-making power. However, it is not easy to break corporate power and turn it to people-centered power, but we can start the process by creating some people-centered action-oriented institutions like Grameen Bank, World Women's Bank, Business Alliance for Local Living Economics (BALE) and Green Belt movement, etc. in all countries. These collective activities could counter multinational corporations and make for people-centered development.

The underlying message of the book The Great Turning is that humanity has come to the end of a long destructive era, and it is time for us to implement people-centered development that promotes social justice, environmentalism and inclusiveness (Korten 1995). We need to break down the profit-motivated capitalist structure and restructure it through Earth Community dialogues which would create healthy communities and recognize the interdependence of all life.

\section{Policy implications}

This book review analysis has revealed that the 'Earth Community' refers to cooperation among community people for the benefit of a people-centered community and a life of well-being. Korten's thoughts on 'Earth Community' help people devise alternative notions that are most suited for the development of a people-centered sustainable green economy, including the participation of different community stakeholders at all levels in the society. For example, according to Korten, in human history women were pioneers of gender equality and generators of a sustainable green gift-economy. His 'Earth Community' term emphasizes and ensures collective human creativity, collective choice and collective voice in an egalitarian agricultural economy, as well as equal resource distribution among community people. Korten's pre-historic earth community condemns male domination in the family. His notion of 'Earth Community' provides us with ideas for working towards an altruistic green economy and gender equality that could increase the opportunity for improving justice and equal accessibility for marginalized people in the society.

Moreover, the book review observes that, due to their nurturing nature, strengthening women's participation in a green economy impacts significantly in protecting deprivation of vulnerable people of the community. Korten's 'Earth Community' not only empowers disadvantaged groups, but also cares for and nurtures the environment and the ecology, and results in stronger communities for facing disasters, and in greater sustainability and green growth of our current society. Korten's book gives us evidence that shows earth communities are empowering marginalised people to create a living economy, living politics and living culture in the world. Moreover, Korten's ideas have great implication for our modern democratic society, where he suggests global corporate empires can even enhance and contribute to altruistic society, valuing local people, local resources, promoting feminism, and fostering egalitarian people-partnerships and structures in the society. He gives us ways for developing consciousness and processes for breaking corporate power, domination and deprivation, and means to start the process of developing people-centred unbiased political representation, 
Rouf, K. R.

community collective programs and actions. In addition, we can develop an earth community that would generate smart altruistic sustainable economics, politics and cultures if we strive to establish justice and implement an 'Earth Community Model' that is suitable to the wellbeing of local people as well as to restoring the ecology of the world.

\section{References}

Korten, D. (2006). The great turning: From empire to earth community. San Francisco: Kumarian Press.

Korten, D. (1995). When corporations rule the world. San Francisco: Kumarian Press, West Hartfield CT \& Berrett Koehler.

Korten, D. (2007). Corporate capitalism and freedom from its domination. Paper presented at the seminar organized by the Faculty of Environmental Studies, York University, and Toronto. October 16, 2007. 